\title{
KEPERCAYAAN MASYARAKAT MEMILIH OBAT HERBAL SEBAGAI ALTERNATIF DALAM PENGOBATAN
}

\author{
Evelyn Nady Damanti \\ Institut Ilmu Kesehatan STRADA Indonesia
}

evelynnady@gmail.com

\begin{abstract}
Abstrak
Sebagian masyarakat masih menggunakan pelayanan kesehatan dari pengobatan tradisional. Pada tahun 2003, sebanyak 30,67\% penduduk Indonesia menggunakan pengobatan alternatif. perilaku adalah suatu kegiatan atau aktivitas organisme (makhluk hidup) yang bersangkutan.

Oleh sebab itu, dari sudut pandang biologis semua makhluk hidup mulai dari tumbuhtumbuhan, binatang, sampai dengan manusia itu berperilaku, karena mereka mempunyai aktivitas masing-masing. Menurut World Health Organization (WHO) yang dimaksud dengan sehat atau health adalah suatu kondisi tubuh yang lengkap secara jasmani, mental, dan sosial, dan tidak hanya sekedar terbebas dari suatu penyakit dan ketidakmampuan atau kecacatan. Obat tradisional adalah ramuan bahan yang bisa berasal dari tumbuhan, hewan, mineral, sediaan sarian atau campuran dari bahan-bahan tersebut yang secara turun-temurun telah digunakan untuk pengobatan berdasarkan pengalaman. Dalam pengobatan Cina ada lima metode pengobatan yaitu akupunktur, obat herbal, pijat (luina), senam relaksasi (qigong) dan feng shui. Hasil penelitian menunjukkan bahwa motivasi pasien berobat ke sinse timbul

karena pasien mempunyai kepercayaan yang salah tentang pengobatan konvensional.

Kepercayaan tersebut adalah adanya kegagalan atau ketidakpastian pengobatan konvensional, ketakutan akan penggunaan obat kimia yang berlebihan serta adanya tindakan operasi pada

penyakit tertentu.
\end{abstract}

\section{Kata Kunci : Kepercayaan, Obat Herbal, Pengobatan}

\section{Latar Belakang}

Sebagian masyarakat masih menggunakan pelayanan kesehatan dari pengobatan tradisional. Pada tahun 2003, sebanyak $30,67 \%$ penduduk Indonesia menggunakan pengobatan alternatif. Selain itu, pada tahun 2003 pemanfaatan obat tradisional yang merupakan bagian dari pengobatan alternatif mempunyai angka yang lebih tinggi 2 kali lipat dari tahun 1999 yaitu $30,67 \%$ dibandingkan dengan $15,04 \%$. Data tersebut menunjukkan adanya kecenderungan semakin meningkatnya penggunaan pengobatan alternatif di masyarakat. Peningkatan penggunaan pengobatan alternatif ini didukung oleh maraknya iklan-iklan pengobatan alternatif di media cetak dan acara-acara konsultasi pengobatan alternatif di media elektronik seperti radio dan televisi. Perkembangan pengobatan tradisional sangat ditentukan oleh tradisi dan kepercayaan masyarakat setempat atau masyarakat lain yang bukan dari barat. Salah satu contoh adat dan budaya yang banyak mempengaruhi perkembangan pengobatan tradisional adalah adat dan budaya Cina. Sistem pengobatan Cina telah berkembang sejak 
ribuan tahun yang lalu. Jumlah sarana dan tenaga kesehatan yang telah mencukupi ternyata tidak mengurangi minat masyarakat dalam pengobatan sinse. Hal ini karena pemilihan pengobatan sinse didasarkan pada metode pengobatan yang sangat cocok dengan karakteristik budaya masyarakat daerah setempat. Menurut kepercayaan kesehatan, seseorang dalam memilih pengobatan ditentukan oleh pengetahuan, motivasi, kepercayaan tentang keberhasilan suatu metode pengobatan, dan adanya faktor yang mendukung tindakan tersebut. Selanjutnya, faktor predisposisi keluarga dalam menggunakan pelayanan kesehatan ditentukan oleh variabel demografik (seperti umur, jenis kelamin, status perkawinan), variabel struktur sosial (seperti pendidikan, pekerjaan, suku bangsa), serta kepercayaan dan sikap terhadap sarana pelayanan kesehatan. Beberapa penelitian menunjukkan bahwa faktor motivasi sangat penting dalam menentukan perilaku manusia dalam perilaku pencarian pengobatan. Motivasi pasien ke pengobatan tradisional karena komunikasi medis tidak memuaskan, takut operasi, dokter menyatakan tidak mampu, serta motivasi ekonomi. Pemilihan masyarakat pada pengobatan tradisional terutama berdasarkan pada kepercayaan tentang kriteria manfaat atau khasiat serta mekanisme pengobatan tradisional. Ada tiga karakteristik pengobatan tradisional yang membuat pasien percaya menggunakan pengobatan tradisional yaitu:

(1) kepercayaan bahwa hidup adalah kesatuan dari badan, emosi, pikiran, dan roh atau jiwa, dan kesehatan adalah keseimbangan antara beberapa aspek di dalam badan manusia dengan lingkungan. Penyakit akan terjadi bila tidak ada keseimbangan antara fisik, emosional, mental atau spiritual.
(2) pengobatan tradisional menggunakan pendekatan menyeluruh pada diagnosis dan tindakan, bukan melihat bagian per bagian tubuh.

(3) pengobatan tradisional berdasarkan pada kebutuhan individu, berbeda orang berbeda tindakan meskipun pada kasus penyakit yang sama. Pemilihan sumber pengobatan yang salah atau terlambat akan menimbulkan dampak yang besar bagi kesembuhan penyakit yang diderita pasien. Guna menghindari kesalahan pengambilan keputusan dalam pemilihan sumber pengobatan, diperlukan upaya pengaturan dan penyelenggaraan pengobatan tradisional. Pemerintah mengatur penyelenggaraan pengobatan tradisional termasuk sinse, dengan tujuan:

(1) membina upaya pengobatan tradisional.

(2) memberikan perlindungan kepada masyarakat.

(3) menginventarisasi jumlah pengobatan tradisional, jenis, dan cara pengobatan. Selain pengaturan penyelenggara pengobatan tradisional, juga diperlukan upaya promosi kesehatan pada masyarakat tentang pemilihan pengobatan alternatif yang aman dan bermanfaat. Dari penjelasan di atas, motivasi, kepercayaan serta kebudayaan merupakan faktor yang paling berpengaruh dalam memilih jenis pengobatan. Untuk itu, dalam melakukan upaya promosi kesehatan diperlukan pengetahuan tentang motivasi dan kepercayaan masyarakat terhadap pengobatan alternatif tersebut.

\section{Kasus/Masalah}

2.1. Saat ini fasilitas dan tenaga Kesehatan di Indonesia sudah menyebar rata di berbagai daerah. Mengapa masih banyak masyarakat yang lebih memilih menggunakan pengobatan herbal daripada pengobatan medis? 


\section{Tinjauan Pustaka}

\subsection{Perilaku Kesehatan}

Dari segi biologis, perilaku adalah suatu kegiatan atau aktivitas organisme (makhluk hidup) yang bersangkutan. Oleh sebab itu, dari sudut pandang biologis semua makhluk hidup mulai dari tumbuh-tumbuhan, binatang, sampai dengan manusia itu berperilaku, karena mereka mempunyai aktivitas masing-masing. Perilaku manusia merupakan hasil dari segala macam pengalaman serta interaksi manusia dengan lingkungannya yang terwujud dalam bentuk pengetahuan, sikap dan tindakan. Dengan kata lain, perilaku merupakan respon atau reaksi seseorang terhadap stimulus yang berasal dari luar maupun dari dalam dirinya. Respon ini bersifat pasif (tanpa tindakan: berpikir, berpendapat, bersikap) maupun aktif (melakukan tindakan). Sesuai dengan batasannya perilaku kesehatan dapat dirumuskan sebagai segala bentuk pengalaman dan interaksi individu dan lingkungannya, khususnya yang menyangkut pengetahuan, sikap tentang kesehatannya serta tindakannya yang berhubungan dengan kesehatan. Menurut L.W. Green, faktor penyebab masalah kesehatan adalah faktor perilaku dan non perilaku. Faktor perilaku khususnya perilaku kesehatan dipengaruhi oleh 3 faktor yaitu :

1. Faktor-faktor predisposisi (Predisposing factors), adalah faktor yang terwujud dalam kepercayaan, keyakinan, nilai-nilai dan juga variasi demografi seperti status ekonomi, umur, jenis kelamin, dan susunan keluarga. Faktor ini lebih bersifat dari dalam diri individu tersebut.

2. Faktor-faktor pemungkin (enabling factors), adalah faktor pendukung yang terwujud dalam lingkungan fisik, yang termasuk di dalamnya adalah berbagai macam sarana dan prasarana, misal : dana, transportasi, fasilitas, kebijakan pemerintah dan sebagainya.

3. Faktor-faktor pendorong (reinforcing factors), adalah faktor-faktor yang meliputi faktor sikap dan perilaku tokoh masyarakat, tokoh agama, sikap dan perilaku petugas termasuk petugas kesehatan, termasuk juga disini undang-undang, peraturan-peraturan baik dari pusat maupun pemerintah daerah yang terkait dengan kesehatan.

\subsection{Teori Health Belief Model (HBM)}

Health belief model dikemukakan pertama kali oleh Resenstock 1966, kemudian disempurnakan oleh Becker, dkk 1970 dan 1980. Sejak tahun 1974, teori Health belief model telah menjadi perhatian para peneliti. Model teori ini merupakan formulasi konseptual untuk mengetahui persepsi individu apakah mereka menerima atau tidak tentang kesehatan mereka. Variabel yang dinilai meliputi keinginan individu untuk menghindari kesakitan, kepercayaan mereka bahwa terdapat usaha agar menghindari penyakit tersebut. Menurut World Health Organization (WHO) yang dimaksud dengan sehat atau health adalah suatu kondisi tubuh yang lengkap secara jasmani, mental, dan sosial, dan tidak hanya sekedar terbebas dari suatu penyakit dan ketidakmampuan atau kecacatan, sedangkan menurut UU No.36 tahun 2009 Tentang Kesehatan, kesehatan adalah keadaan sehat, baik secara fisik, mental, spiritual maupun sosial yang memungkinkan setiap orang untuk hidup produktif secara sosial dan ekonomi. Belief dalam bahasa inggris artinya percaya atau keyakinan. Menurut peneliti belief adalah keyakinan terhadap sesuatu yang menimbulkan perilaku tertentu. Misalnya individu percaya bahwa belajar sebelum ujian akan berpengaruh terhadap nilai ujian. Jenis kepercayaan tersebut terkadang tanpa didukung teori teori lain yang dapat dijelaskan secara logika. Model adalah 
seseorang yang bisa dijadikan panutan atau contoh dalam perilaku, cita-cita dan tujuan hidup yang akan dicapai individu. Dalam materi peneliti kali ini teori modeling di umpamakan sebuah issue atau pengalaman pengobatan dari seseorang yang memiliki riwayat sakit yang sama dan memilih serta menjalani pengobatan alternative yang mendapatkan hasil yang positif. Health belief model merupakan suatu konsep yang mengungkapkan alasan dari individu untuk mau atau tidak mau melakukan perilaku sehat (Janz \& Becker, 1984). Health belief model juga dapat diartikan sebagai sebuah konstruk teoretis mengenai kepercayaan individu dalam berperilaku sehat (Conner, 2005). Health belief model adalah suatu model yang digunakan untuk menggambarkan kepercayaan individu terhadap perilaku hidup sehat, sehingga individu akan melakukan perilaku sehat, perilaku sehat tersebut dapat berupa perilaku pencegahan maupun penggunaan fasilitas kesehatan. Health belief model ini sering digunakan untuk memprediksi perilaku kesehatan preventif dan juga respon perilaku untuk pengobatan pasien dengan penyakit akut dan kronis. Namun akhir-akhir ini teori Health belief model digunakan sebagai prediksi berbagai perilaku yang berhubungan dengan Kesehatan.

\subsection{Obat Herbal/Obat Tradisional}

Obat tradisional adalah ramuan bahan yang bisa berasal dari tumbuhan, hewan, mineral, sediaan sarian atau campuran dari bahan-bahan tersebut yang secara turuntemurun telah digunakan untuk pengobatan berdasarkan pengalaman (UU kesehatan No.23/1992). Istilah obat herbal sendiri mengacu pada kata herb yang berarti tanaman, yaitu obat yang berasal dari tanaman atau tumbuhan. Obat herbal dapat berasal dari akar, batang, daun, buah, atau biji suatu tanaman. Terdapat tiga kategori obat herbal yaitu jamu, herbal terstandar, dan fitofarmaka. (Sari et al. 2008). Param termasuk dalam kategori obat herbal jamu.

Jenis obat tradisional Berdasarkan keputuan Kepala Badan POM RI No.HK.00.05.4.2411. tentang ketentuan pokok pengelompokan dan penandaan obat bahan alam Indonesia, obat tradisional dikelompokkan menjadi tiga yaitu jamu, herbal terstandar, dan fitofarmaka.

A. Jamu (Emphirical Based Herbal Medicine) adalah obat tradisional yang berisi seluruh bahan tanaman yang menjadi penyusun jamu tersebut. Jamu disajikan secara tradisional dalam bentuk serbuk seduhan, pil, atau cairan. Umumnya obat tradisional ini dibuat dengan mengacu pada resep peninggalan leluhur. Satu jenis jamu disusun dari berbagai tanaman obat yang jumlahnya antara 5-10 macam, bahkan bisa lebih. Jamu yang telah digunakan secara turun-temurun selama berpuluh-puluh tahun bahkan ratusan tahun telah membuktikan keamanan dan maanfaat secara langsung untuk tujuan kesehatan tertentu.

B. Obat Herbat Terstandar (Standarized Based Herbal Medicine) merupakan obat tradisional yang disajikan dari hasil ekstraksi atau penyarian bahan alam, baik tanaman obat, binatang, maupun mineral. Dalam proses pembuatannya, dibutuhkan peralatan yang tidak sederhana dan lebih mahal dari pada jamu. Tenaga kerjanya pun harus didukung oleh pengetahuan dan keterampilan membuat ekstrak. Obat herbal ini umumnya ditunjang oleh pembuktian ilmiah berupa penelitian praklinis. Penelitian ini meliputi standardisasi kandungan senyawa berkhasiat didalam bahan penyusun, standardisasi pembuatan ekstrak yang higienis, serta uji toksisitas yang akut maupun kronis. 
C. Fitofarmaka (Clinical Based Herbal Medicine) merupakan obat tradisional yang dapat disejajarkan dengan obat modern. Proses pembuatannya telah terstandar dan ditunjang oleh bukti ilmiah sampai uji klinis pada manusia. Karena itu, dalam pembuatannya diperlukan peralatan bertehnologi modern, tenaga ahli, dan biaya yang tidak sedikit(Suharmiati at al.2000)

Pengobatan tradisional adalah salah satu upaya pengobatan dan perawatan, diluar kedokteran dan ilmu keperawatan. Pengobatan secara tradisional ini mencakup cara dan obat yang digunakan mengacu pada pengetahuan, pengalaman, dan keterampilan yang diperoleh secara turuntemurun. Dan dilakukan untuk mencapai kesembuhan, pencegahan penyakit, pemulihan, dan peningkatan kesehatan jasmani, rohani, dan sosial masyarakat(Noorkasiani.2007)

\section{Pembahasan}

4.1. Masyarakat lebih memilih menggunakan pengobatan herbal daripada pengobatan medis.

Dalam pengobatan Cina ada lima metode pengobatan yaitu akupunktur, obat herbal, pijat (luina), senam relaksasi (qigong) dan feng shui. Metode pengobatan yang sering digunakan sinse hanya tiga macam yaitu akupunktur, obat herbal, dan pijat. Pada umumnya obat-obatan yang digunakan sinse diimpor dari Negara Cina. Motivasi dan Kepercayaan Pasien untuk Berobat ke Sinse, Abdul Haris Jauhari, dkk. Jumlah sinse yang melakukan praktik pengobatan di daerah tertentu bersifat stagnan dan bahkan mengalami penurunan seiring dengan perkembangan zaman. Hal ini disebabkan sinse yang ada sebagian besar telah berusia tua, dan ketidaktertarikan generasi muda mempelajari ilmu pengobatan Cina. Faktor sulitnya mempelajari ilmu pengobatan Cina, membutuhkan waktu yang lama, serta kendala bahasa yang sulit dimengerti merupakan faktor yang menghambat perkembangan praktik pengobatan Cina. Berdasarkan hasil wawancara pada informan, umumnya sinse memperoleh ilmu pengobatan dari faktor keturunan. Namun demikian, kemampuan seorang sinse sangat ditentukan oleh bakat dan kemampuan sinse dalam mengembangkan ilmu yang diperoleh baik melalui pendidikan maupun pengalaman yang diperoleh selama melakukan praktik. Hasil penelitian menunjukkan bahwa motivasi pasien berobat ke sinse timbul karena pasien mempunyai kepercayaan yang salah tentang pengobatan konvensional. Kepercayaan tersebut adalah adanya kegagalan atau ketidakpastian pengobatan konvensional, ketakutan akan penggunaan obat kimia yang berlebihan serta adanya tindakan operasi pada penyakit tertentu. Kepercayaan tersebut mendorong pasien untuk mencari alternatif pengobatan lain yang dinilai tepat. Berdasarkan informasi dan pengalaman tentang pengobatan yang diterima, maka pasien akan mulai mencari alternatif atau mencoba-coba pengobatan selain pengobatan konvensional. Penggunaan obat-obat kimia secara terusmenerus dengan dosis tinggi bagi pasien dengan penyakit kronis menimbulkan ketakutan pasien akan dampak yang ditimbulkan. Ada kepercayaan pasien sinse bahwa penggunaan obat-obat kimia sangat berbahaya bagi dirinya. Ketakutan ini dipengaruhi oleh informasi yang diterima masyarakat bahwa penggunaan bahanbahan kimia pada obat-obatan akan menimbulkan dampak kerusakan ginjal dan organ tubuh lainnya. Hal ini menimbulkan motivasi bagi pasien untuk mencari pengobatan yang menggunakan bahanbahan alami yang berasal dari tanaman. Pasien percaya bahwa bahan-bahan alami 
akan lebih aman di tubuh, meskipun ada pasien yang mengkhawatirkan kebersihan dari bahan-bahan tersebut. Pasien percaya sinse memiliki kemampuan dalam mengobati penyakit kronis.

Proses pengobatan konvensional pada penyakit kronis ini kadang-kadang kurang efektif atau tidak dapat menyembuhkan. Proses penyakit dapat dikendalikan tetapi tidak dapat dipulihkan ke keadaan semula. Proses pengobatan yang lama serta kurang efektif ini menjadikan menurunnya kepercayaan pasien terhadap pengobatan konvensional. Pasien beranggapan pengobatan konvensional telah gagal atau menimbulkan ketidakpastian. Hal ini menimbulkan motivasi pasien untuk mengalihkan pengobatannya. Penelitian pada penderita kanker, menemukan bahwa pasien yang mencari pengobatan tradisional karena beranggapan dokter tidak mampu menyembuhkannya. Pengobatan konvensional akan melakukan tindakan operasi guna menangani kasus penyakitpenyakit tertentu seperti tumor, kanker, amandel, dan lain-lain. Sebagian masyarakat Indonesia sangat takut akan tindakan operasi ini, sebagaimana alasan penderita kanker yang berobat ke pengobatan tradisional sebanyak 59,6\% karena takut operasi. Anggapan masyarakat bahwa operasi akan menimbulkan risiko besar dan membutuhkan biaya yang relatif tinggi dibandingkan dengan berobat ke sinse. Berbagai kepercayaan masyarakat tentang pengobatan konvensional tersebut akibat kurang jelasnya informasi yang diterima masyarakat yang disebabkan oleh pola komunikasi dokter dengan pasien yang tidak baik. Komunikasi yang harusnya bersifat timbal-balik bergantian peran menjadi pemberi dan penerima informasi tidak terjadi pada komunikasi dokterpasien. Kebanyakan dokter ternyata bukan pendengar yang baik. Dokter aktif memberikan penjelasan tentang penyakit pasien, akan tetapi jarang memperhatikan pendapat pasien. Dokter sering menganggap pasien sudah paham akan penjelasannya tentang pengobatan yang akan dilakukan. Kenyataannya, pasien kurang mengerti tentang penjelasan tersebut, sedangkan harga diri dan rasa malu pasien menghalangi untuk minta penjelasan lebih lanjut. Kesalahan ini sebenarnya dapat dikurangi dengan memperbaiki komunikasi antara pasien dan dokter. Untuk mengatasi hal ini, komunikasi antara dokter dan pasien perlu lebih ditingkatkan dengan memberikan informasi sejelas mungkin mengenai penyakit yang diderita serta tindakan medis yang akan dilakukan.

Hipotesis dalam Health Belief Model (HBM) menyatakan bahwa seseorang tidak akan mencari pertolongan medis bila kurang mempunyai pengetahuan dan motivasi terhadap pelayanan kesehatan. Dengan demikian, dalam melakukan tindakan medis tentunya seseorang akan mengumpulkan informasi tentang tindakan medis yang dilakukan serta melakukan penilaian baik keuntungan maupun kerugian (fisik, uang dan lain-lain) yang harus dikeluarkan untuk melaksanakan tindakan. Kepercayaan pasien tentang keuntungan dan kerugian berobat ke sinse juga memotivasi pasien untuk berobat ke sinse. Pasien percaya bahwa kerugian yang diterima yaitu: penggunaan obat yang tidak praktis, tidak enak, dan kebersihan tidak terjamin. Hal ini tidak sebanding dengan Motivasi dan Kepercayaan Pasien untuk Berobat ke Sinse, Abdul Haris Jauhari, dkk. keuntungan yang diterima yaitu biaya lebih rendah, kecilnya risiko penggunaan obat herbal serta tujuan dari pengobatan yaitu kesembuhan.

\subsection{Opini Penulis}

Dengan adanya kepercayaan masyarakat terhadap pengobatan sinse/herbal membuat 
minat masyarakat terhadap pengobatan konvensional menurun, beberapa orang kadang meninggalkan pengobatan medis dan beralih ke tradisional/herbal. Padahal pengobatan konvensional dan tradisional terhubung dan saling melengkapi. Saat sakit imun seseorang menjadi turun, dengan adanya obat herbal bisa menambah stamina dan daya tahan tubuh kembali stabil. Pemahaman yang seperti inilah yang harusnya diberikan terus menerus kepada masyarakat. Jangan langsung melakukan pengobatan tradisional atau meracik sendiri tanaman obat yang dipercaya dapat mengobati suatu penyakit. Tetap harus ke dokter untuk mendapatkan pengobatan yang sesuai diagnosis. Yang paling penting adalah mengubah perilaku sehari-hari yaitu lebih baik mencegah daripada mengobati misalnya menggunakan tanaman herbal sebagai upaya pencegahan, contohnya membudayakan minum jamu sebagai promotive dan preventif. Tentunya diimbangi dengan olahraga dan memperhatikan asupan makanan dan minuman sehari-hari.

\section{Kesimpulan}

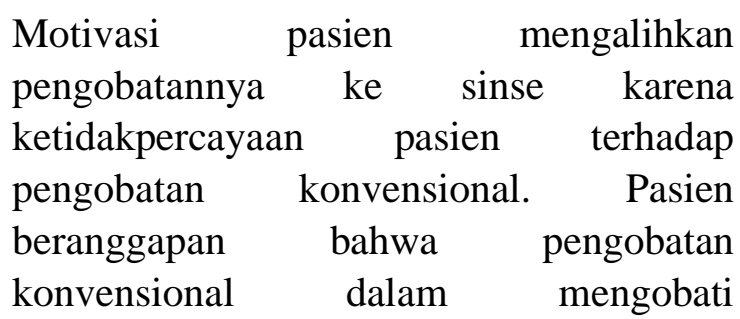
penyakitnya telah gagal/tidak pasti, serta kepercayaan pasien bahwa penggunaan obat-obatan kimia akan menimbulkan dampak bagi organ tubuh. Selain itu, pengobatan sinse lebih menguntungkan dibandingkan dengan pengobatan konvensional karena pengobatannya tuntas, murah, serta alami. Kerugian pengobatan sinse menurut pasien yaitu obatnya tidak praktis, tidak enak, serta tidak terjamin kebersihannya. Jangan langsung melakukan pengobatan tradisional atau meracik sendiri tanaman obat yang dipercaya dapat mengobati suatu penyakit. Tetap harus ke dokter untuk mendapatkan pengobatan yang sesuai diagnosis. Yang paling penting adalah mengubah perilaku sehari-hari yaitu lebih baik mencegah daripada mengobati.

\section{Daftar Pustaka}

Siyoto, S., \& Sodik, M. A. (2015). Dasar metodologi penelitian. Literasi Media Publishing.

Sodik, M. A. (2014). Sikap Pencegahan Aborsi Ditinjau Dari Pengetahuan Tentang Bahaya Dan Resiko Kesehatan. Strada Jurnal Kesehatan http://publikasi. stikesstrada. ac. id/wpcontent/uploads/2015/02/9-SIKAPSIKAPPENCEGAHAN-ABORSI. pdf.

Sodik, M. A., \& Nzilibili, S. M. M. (2017). The Role Of Health Promotion And Family Support With Attitude Of Couples Childbearing Age In Following Family Planning Program In Health. Journal of Global Research in Public Health, 2(2), 8289.

Jauhari, A. H., Utami, M. S., \& Padmawati, R. S. (2008). Motivasi dan Kepercayaan pasien untuk Berobat ke Sinse. Berita Kedokteran Masyarakat, 24(1), 1-7.

Fanani, S., \& Dewi, T. K. (2014). Health belief model pada pasien pengobatan alternatif supranatural dengan bantuan dukun. Jurnal psikologi klinis dan kesehatan mental, 3(1), 54-59. 